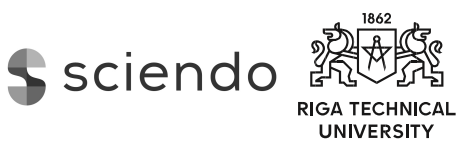

ISSN: 2255-9671 (online)

2018, 6, 88-99

doi: 10.2478/bjreecm-2018-0007

http://www.degruyter.com/view/j/bjreecm

\title{
ECO-ECONOMICS IN CITIES AND RURAL AREAS
}

\author{
Jānis ZVIRGZDIN̦Š' ${ }^{1}$, Kaspars PLOTKA ${ }^{2}$, Sanda GEIPELE ${ }^{3}$ \\ ${ }^{1-3}$ Riga Technical University, Riga, Latvia \\ Corresponding author's e-mail: Janis.Zvirgzdins_1@edu.rtu.lv
}

\begin{abstract}
Economic models are built primarily following the classical economic theories, but a challenge to build good models with classical theories is needed to define the exact value of the Earth, which is hardly definable. Quite often national gross product indicator calculation reuses the same performance indicators, where the resource and income distribution system is not linked to production factors. The resource and income distribution system is primarily associated with low productivity (execution of a sales plan, execution of a profit plan, profitability level, increase in market share, personnel turnover rate, hours worked per employee). Changes in the productive and economic structures of the markets result in new innovative growth patterns which, based on customer motivation, are linked to the concentration of capital in regional and national markets, the growth of transnational markets and the development of technology. At the same time, extensive economic development through natural resources leads to deforestation, landscape changes, desertification, swamping and soil fertility renewal. So far, it often has been assumed that economic growth depends on the use of natural resources, and natural resources are unlimited. The results are "resource crisis": resources are running out and resource prices are rising, thus invalidating a particular model. On the other hand, the ecoeconomy approach is a sustainable future for the economic modelling. The principle of eco-economy is based on a production system, which relies on re-cyclicality (the basis is the production of zero waste production). For this to happen, a transition to a completely new mindset is needed. The research results were previously approbated during the graduate meeting of the Baltic DBU scholarship holders from 4 to 6 May 2018 in Latvia.
\end{abstract}

Keywords: Circular economy, cities, green economy, rural areas, synergy.

\section{INTRODUCTION}

The importance of ecology is becoming increasingly important in the $21 \mathrm{st}$ century. Nowadays, society and economists are more frequently searching for an alternative economic model, in which prosperity can be created without harming the environment, because air and water pollution, deforestation are problems that 
are more and more evident and directly impacting the quality of life for most of the people. Environment degradation is also becoming increasingly unsuitable for many species, including all types of plants, animals and many water species.

Economics is a system of production, distribution, exchange and consumption of goods and services. In addition, economics is a science that studies ways to make the most effective use of available limited resources.

The basis of the economy is the production of goods and services. Without production, there would not be any trade, exchange of goods and consumption of produced goods. In connection with the limited resources and the not limited human needs, it is necessary to save resources. This is the reason for the economy to be considered as a science. The economy in any society should answer the following questions: What goods and services should be produced; how goods and services should be produced; are the produced goods and services demanded; in what quantities; is the production sustainable?

Depending on how resource allocation, production and exchange process management issues are solved, the following main types of economic systems are distinguished: traditional economy, market economy, command economy and mixed economy.

In the 21 st century, there is transformation as a demand for interdisciplinary economies.

\section{METHODS AND PROCEDURES}

The authors of the article use a systematic search and review as a research method.

Systematic reviews target to address these problems:

- to determine to what extent existing research has progressed to identify a specific problem;

- to identify relations, gaps, contradictions and inconsistencies in the literature and explore their causes;

- to formulate general statements or a comprehensive concept (Grant \& Booth, 2009; Brereton, Kitchenham, Budgen, Turner, \& Khalil, 2007; Boell \& Cecez-Kecmanovic, 2015; McKinstry, Brown, \& Gustafsson, 2014).

Environmental problems related to the extraction and processing of many materials and natural resources move from Europe to the exporting countries concerned. Consequently, the impacts of European consumption and resource use on the global environment are increasing. As resource use in Europe exceeds local availability, European dependence and competition in terms of resources from other parts of the world, in the long run, raise questions about the security of supply of resources in Europe and create the potential for future conflicts (Matthew, Brown \& Jensen, 2009; European Environment Agency, 2011).

The authors study the synergy aspects of geo-economy, ecological economy, bioeconomy, green economy and circular economy for the development of urban and rural areas in the 21 st century. 


\section{RESULTS AND DISCUSSION}

"In economics, for example, a typical distinction is made between partial equilibrium analysis and general equilibrium analysis. In partial equilibrium analysis, a subsystem (a single market) is studied with the underlying assumptions that there are no important feedback loops from other markets. In general equilibrium analysis, on the other hand, the totality of markets are studied to bring out the general interdependence in the economy. The large-scale, whole-economy, general equilibrium effects are usually quite different from the sum of the constituent small-scale partial equilibrium effects. In addition, it is consent, that model observations and their further complication that in reality the true equilibrium is never achieved, and one can begin to see the limitations of classical, reductionist science in understanding complex systems" (Costanza, Wainger, Folke, \& Mäler, 1993).

Geoeconomics by definition is "economics in its relationship to such geographical conditions as for location and natural resources" (Yourdictionary.com, n. d.). Geoeconomics is based on a new geopolitical approach from the country, which shows how global wage is disseminated across different countries. From a civil authority point of view, this is an important aspect of internal politics, which is linked to provincial power.

Therefore, nations will tend to act 'geo-economically' simply because of what they are: spatially-defined elements organised to exceed each other on the world scene. For the various capacities that countries have acquired as suppliers of specific benefits, classified services and diverse infrastructures, their reason of being and the ethos that sustains them still derive from their chronologically first function: to provide protection from enemies. Relatively few countries have had to fight to exist, but all countries exist to fight - or at least they are organised as if it was their dominant function. Correspondingly, intergovernmental rivalry, as a matter of importance, must be carried out by utilising economical methods. These days, considering that the utilisation of military power is going to the second stage, on the international level the ranking of countries is considered only by economic strength. Today, we see that geopolitics has already been partially replaced by geoeconomics. In a more extensive sense, geoeconomics does not oppose geopolitics. To achieve geopolitical goals, geoeconomics uses economical ways, just as geo-strategy employs military ones (Kvinikadze, 2016).

The Chair of the Global Agenda Council on Geo-economics Mark Leonard has said that with tension increase between great powers global businesses increasingly find that political risk is no longer just instability in the developing world or avoiding war zones. The global financial system has become a battlefield regarding sanctions, consumer boycotts, preferential treatment for national champions and the creation of open markets increases the possibility of protractedly accumulated investment disappearing in a short period of time. In addition, the impacts on business and people who intend for trade as a way of lifting people out of poverty are deeply concerning (Cann, 2015).

The hypothesis of the authors is that for sustainable growth new national approaches need to be defined. Many scientists have identified approaches and 
performed several studies about aspects of soil degradation on economic development (Bashaasha, Mangheni \& Nkonya, 2011; von Braun, Gerber, Mirzabaev, \& Nkonya, 2013; Bojö, 1991; Nkonya, Gerber, von Braun, \& De Pinto, 2011; Qadir et al., 2014; Nkonya, Mirzabaev \& von Braun, 2016).

Those agricultural methods and results, which with eco-modernisation and increase of production efficiency also raise the quality of life and living environment quality improvements, are considered part of 'green' economy. At the same time, in many official documents of national programmes totally different aspects and factors are featured: to develop competition between incumbent companies, to support growth activities for additional workplaces, which are aligned with the defined green economy factors. In developing countries, the primarily focus is placed on economic development, poverty aspects as a priority, equality issues, citizen involvement and effective green policy of the country.

Eco-economy, bioeconomy and green economy are a solution proposed by Europe for the main environmental challenges the world is facing nowadays. It is focused on reducing the dependence on natural resources, transforming production, promoting sustainable manufacturing of renewable resources from land, aquaculture and fisheries and converting them into food, feed, fibre, biobased products and bio-energy, while increasing the number of new jobs and developing industries (European Commission, n. d.).

Bioeconomy includes primary production (agriculture, forestry, fisheries, aquaculture) and industries using and processing biological resources (food, pulp and paper), and parts of the chemical, biotechnological and energy industries. "The bio-economy is meant to achieve policy objectives that were listed in the first draft of the European Strategy and Action plan towards a sustainable biobased economy by 2020" (European Commission, n. d.). These objectives are as follows:

1) reinforcing European leadership and creativity in the biosciences;

2) optimising innovation and the systems for knowledge transfer;

3) research into safe, nutritious and affordable food;

4) making rural and coastal economies more sustainable;

5) improving the efficiency of agricultural, food and industrial production and distribution systems;

6) maintaining the competitiveness of European industry and agriculture;

7) building low-carbon industries;

8) reducing emissions of greenhouse gasses and waste (Schmidt, Padel, \& Levidow, 2012).

Cities are particularly vulnerable to climate change and climate extremes in particular because they concentrate many activities, people and wealth in small areas. As a result, they represent an important scale for assessment and understanding of climate change impacts (Hallegatte, Henriet \& Corfee-Morlot, 2011; Shao, Tang, Zhang, \& Li, 2006; Robinson, 2017; Naeem, Cao, Waqar, Wei, \& Acharya, 2018; Wende \& Darbi, 2018). 
Bioeconomy, as defined in Horizon 2020 programme, is managed in a sustainable manner, and bioeconomy can also:

1) sustain a wide range of public goods, including biodiversity and ecosystem services;

2) reduce the environmental footprint of primary production and the supply chain as a whole;

3) increase competitiveness;

4) enhance Europe's self-reliance;

5) provide jobs and business opportunities (European Commission, n. d.).

In brief, bioeconomy can contribute to building a more competitive, innovative and prosperous Europe.

The concept of green economy is based on several sectors as an ecosystem, economy and human well-being (Fig. 1). Sustainable economic development can be achieved, if all these sectors are in synergy.

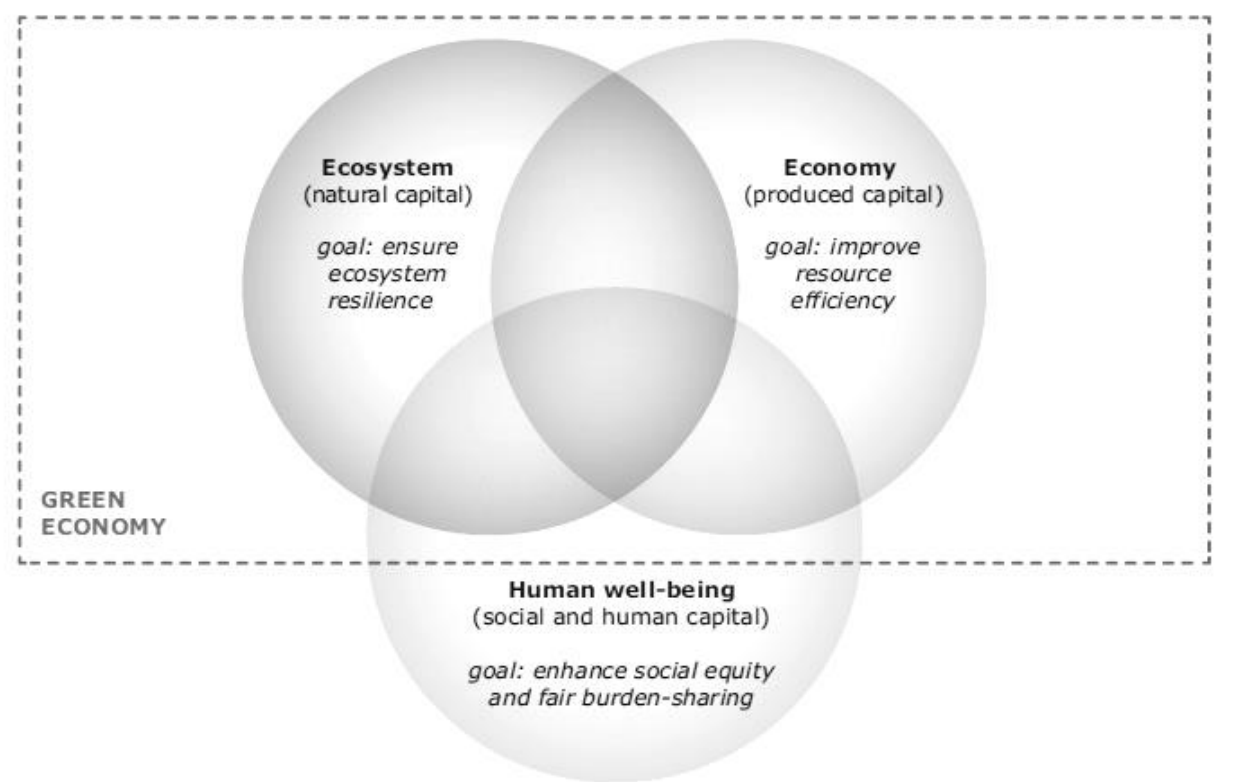

Fig. 1. The 'green economy concept' in the context of sustainable development (Martin \& Henrichs, 2012).

Circular economy: "The circular economy concept can be traced back many decades. In making the case for a circular rather than linear flow of material resources in the economy, Boulding (1966) drew an analogy from manned space exploration by advocating a shift from the 'cowboy economy' (endless frontiers/resources and the ability to move on and abandon problems) to the 'spaceship economy' where limited resources had to be reused and recycled as a precondition to sustainable life-support systems. The concept has since been developed at a theoretical level and as part of environmental economics by many authors (for example Smith (1972), Mäler (1974) and Dasgupta and Heal (1979))" (European Academies' Science Advisory Council, 2015).

There are essential differences among linear, reuse and circular economies (Fig. 2). The global population is growing and it has an impact on the 
environment. To ensure that there are enough food, water and wealth in 2050 , we need to switch from a linear to a circular economy. The goal is to ensure healthy and safe living and working conditions and cause less harm to the environment. For a long time, our economy has been 'linear'. This means that the raw materials are used to make the product, and all waste is discarded after use. In the recycling economy, materials are being reused. For example, waste paper is used for new papermaking. To ensure that there will be enough raw materials for food, housing, heating and other needs in the future, our economy should become circular. This means eliminating waste by making products and materials more efficient and reusing them. If new raw materials are needed, they must be sustainable in order not to harm the natural and human environment (Government of the Netherlands, n. d.).
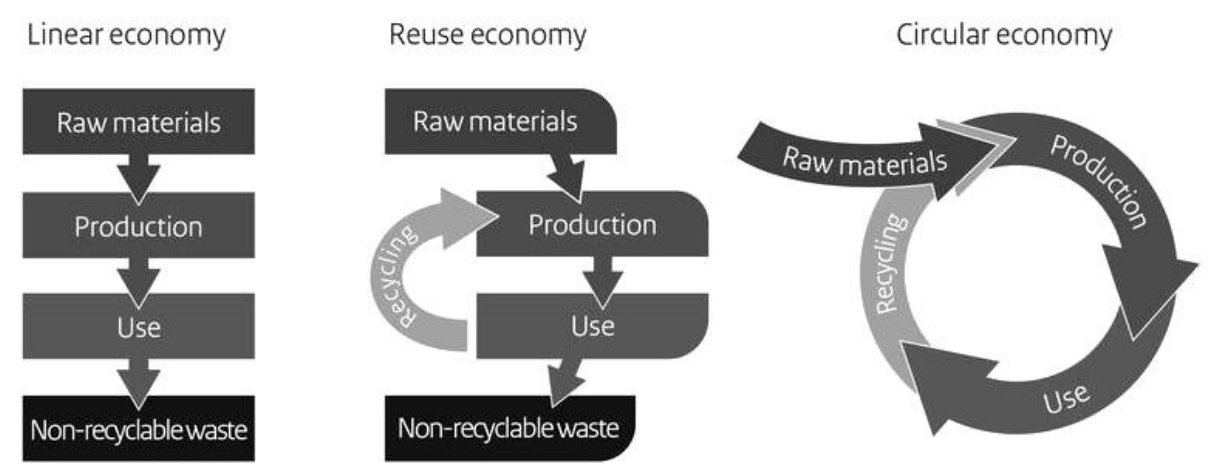

Fig. 2. From a linear to a circular economy (Government of the Netherlands, n. d.).

The circular economy is referred to as future economy developed on a sustainable approach for solving topical issues (Fig. 3). The issue of climate adaptation in rural and urban areas due to greenhouse gases and global warming is discussed most among scientists (Gill, Handley, Ennos, \& Pauleit, 2007; Mirza, 2003; Birkmann, Garschagen, Kraas, \& Quang, 2010; Tupenaite, Lill, Geipele, \& Naimaviciene, 2017). It causes challenges for water management (Vorosmarty, et al., 2000; Meijide, et al., 2017). As the global consumption grows, the provisioning of food, resources and fossil fuels becomes a national-scale issue (Meadows et al., 1972; Forde, 2017; Li, Omani, Chaubey, \& Wei, 2017; KotvalK, Meitl \& Kotval, 2017). The reuse of space, removal of landfill sites and recovery of brownfields play an important role in sustainable global human wellbeing regarding a growing number of global population (Bookchin, 1987, de Groot et al., 2010, Kotval-K, Meitl \& Kotval, 2017; Burlakovs et al., 2017; Breure, Lijzen, Maring, 2018).

Development of biomass and biogas is an essential factor to reduce the use of fossil fuel and the suitable mean of reusing materials regarding circular economy (Ramirez-Almeyda et al., 2017; Hetemäki et al., 2017). Overall, circular economy has potential to provide successful synergy between rural areas and cities to reduce the negative impact of urbanization (Jiang \& O'Neill, 2017). 


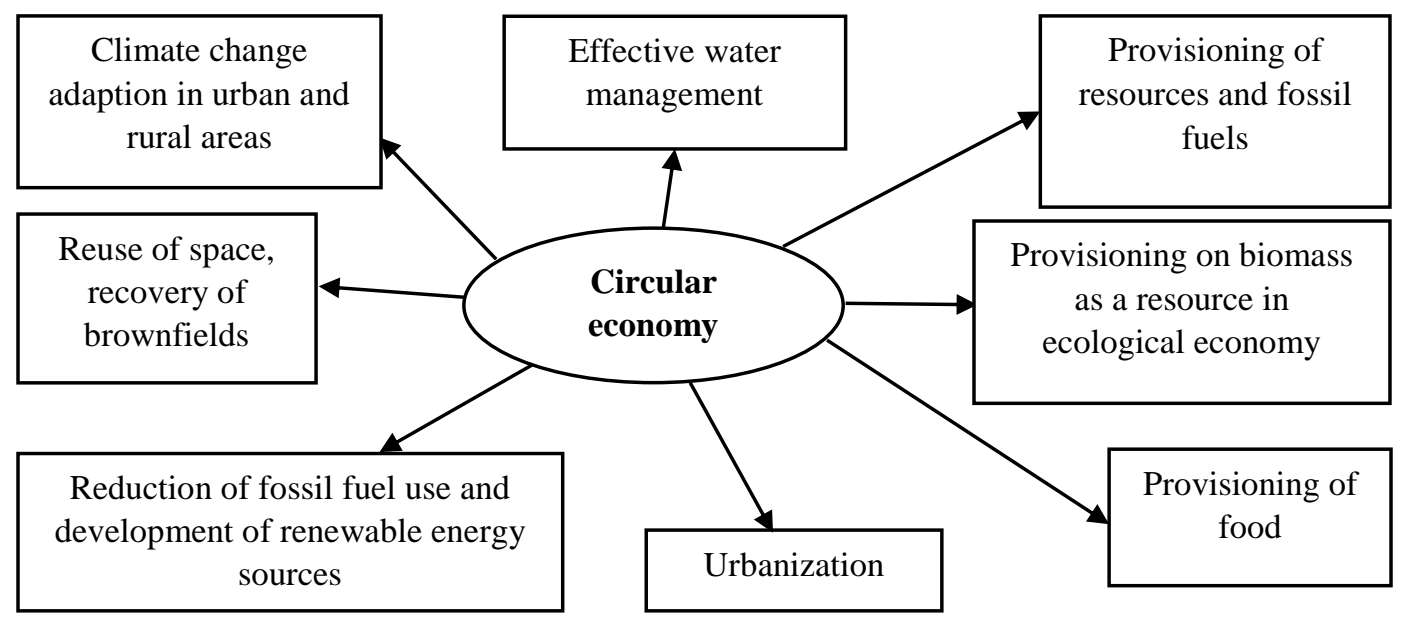

Fig. 3. Societal issues solved using circular economy (made by the authors).

For the circular economy to become reality, important factors are knowledge accumulation, progress control and assurance to supply policymakers with data and information, and to assure sufficient comprehension for the ability to develop supportive and elastic policies. This is one of the main responsibilities of the European Environmental Agency.

The authors of the article offer their vision of the relations regarding agriculture, forestry, climate, water management and energy between economies described above (Fig. 4). The highest synergy is identified between green economy and circular economy, which can provide sustainable development in an urban environment and rural areas. Additionally, all of these relations are part of geoeconomics.

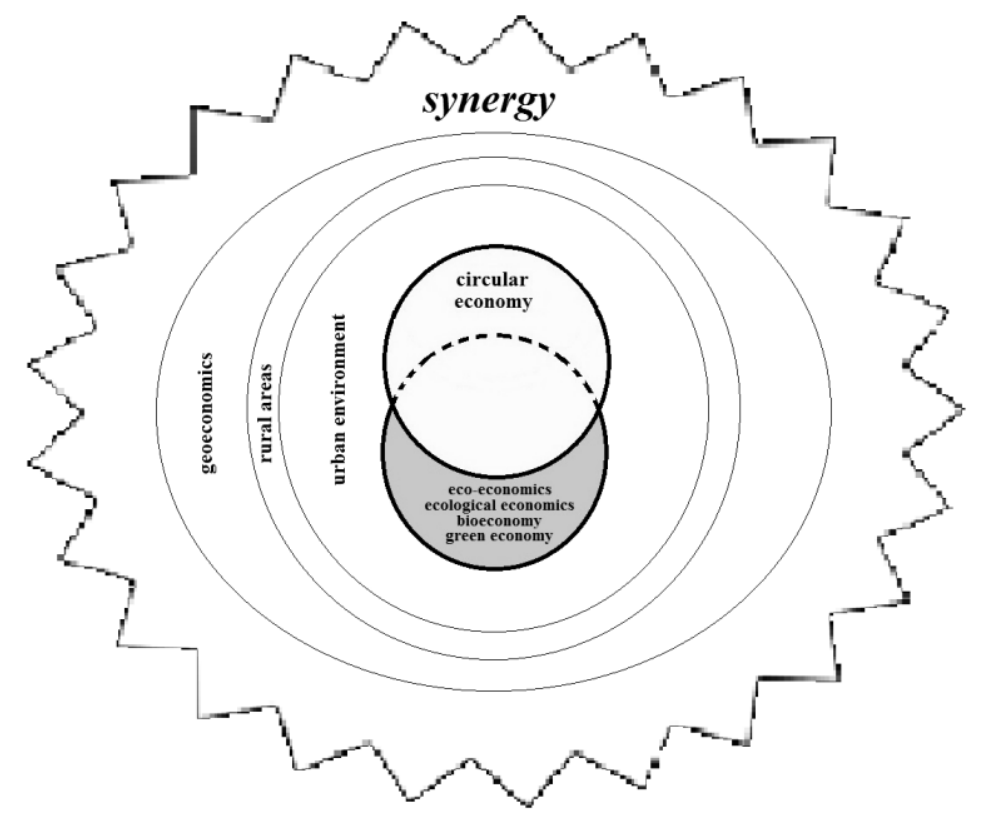

Fig. 4. The synergy between the concepts of green economies and circular economy (made by the authors). 
Green economy as per understanding in 2018 is connected with technological equipment development, manufacturing and promotion of other activities to reduce pollution and greenhouse effect gas emissions and to control monitoring of climate change and modelling. Green economy activities also include energy and resource preservation technologies for renewable energy resource integration in cities and rural areas.

The authors of the article offer a landscape development model in rural areas regarding eco-economical aspects and processes (Fig. 5).

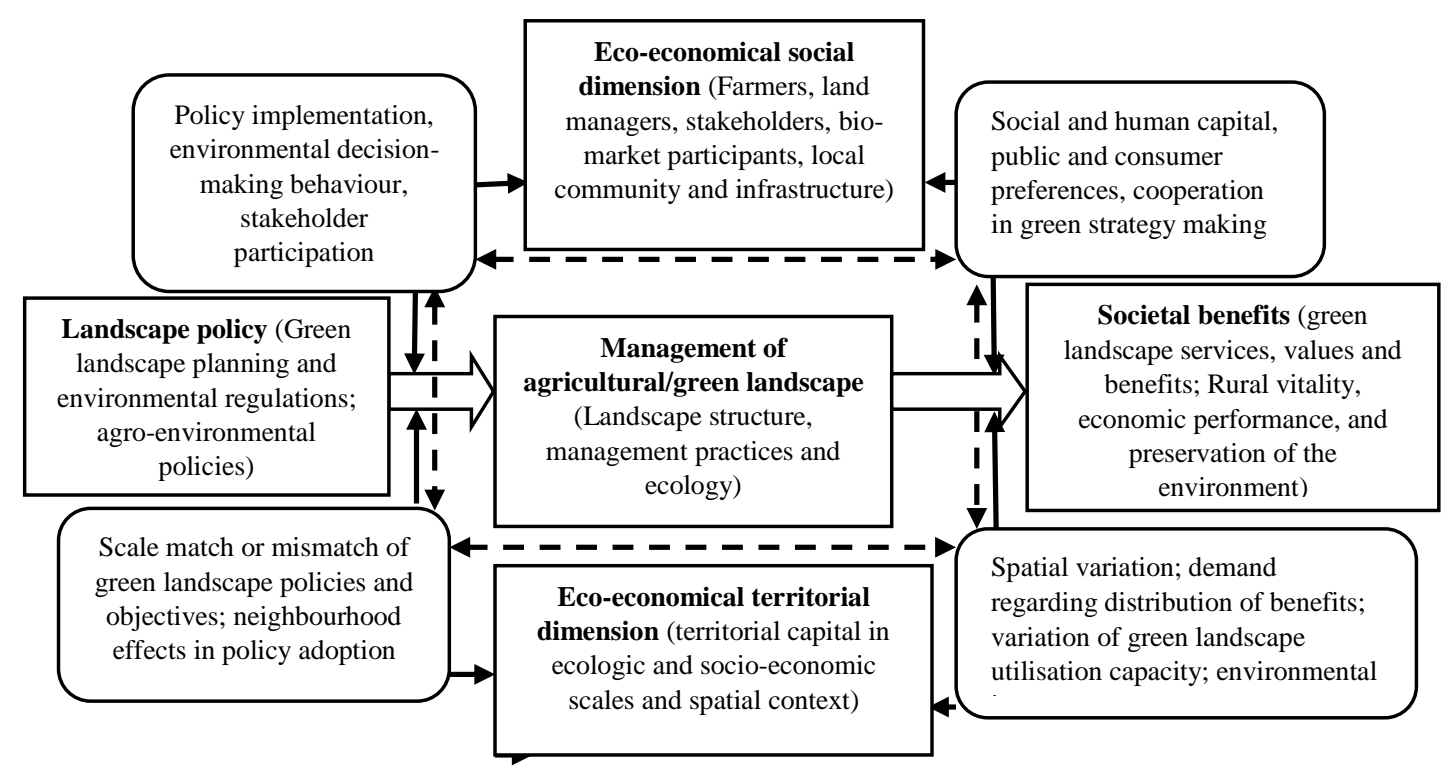

Fig. 5. Landscape development model in rural areas (made by the authors).

In 1981, the Nobel Prize was awarded to James Tobin "for his analysis of financial markets and their relations to expenditure decisions, employment, production and prices" (Nobelprize.org, n.d.). Green economists have raised initiative to establish Tobin tax, with tax rate $1 \%$ of all international deals, and to move those funds to poor countries to reduce growing differentiation between developed and developing countries (Barbier, 2011; Patomäki, 2001; Grahl \& Lysandrou, 2003; Buiter, 2003; Stecher \& Bailey, 1999).

\section{CONCLUSION}

We are in the process of major digital transformation, where the increasingly important role is the ability to adapt to the economy of the whole country. It is a critical need to support organisations and public governance to define sustainable strategies and policies for development. Timely definition of long-term sustainable strategies in policies would enable innovations and support the growth of economics with a high impact on the development of rural and urban environment as a whole system.

The circular economy has a trait for a positive impact not only on a separate country environment but also extends a positive impact across borders with direct 
influence on life quality and living environment of many people. This trait also directly links economics of different countries. Despite many benefits of the circular economy, transition to circular and eco-economics is postponed for an undefined period. In addition, global companies with a high impact on public opinion are not yet able to become sufficiently impulsive for change. Society primarily seeks short-term goals with less evaluation on long-term consequences, as the primary targets are defined by an artificially maintained consumer concept to 'live easy'. There is a challenge to overcome psychological barriers and to assure that there are many chances for success and benefits in green concepts, and how quickly and efficiently reach a large proportion of society is still an open issue.

The research results were previously approbated during the graduate meeting of the Baltic DBU scholarship holders from 4 to 6 May 2018 in Latvia.

\section{REFERENCES}

Barbier, E. (2011). The Policy Challenges for Green Economy and Sustainable Economic Development. Natural Resources Forum, 35(3), 233-245. https://doi.org/10.1111/j.1477$\underline{\text { 8947.2011.01397.x }}$

Bashaasha, B., Mangheni, M. N., \& Nkonya, E. (2011, February). Decentralization and Rural Service Delivery in Uganda. International food policy research institute (IFPRI) Discussion Paper 01063.

Birkmann, J., Garschagen, M., Kraas, F., \& Quang, N. (2010). Adaptive Urban Governance: New Challenges for the Second Generation of Urban Adaptation Strategies to Climate Change. Sustainability Science, 5(2), 185-206. https://doi.org/10.1007/s11625-010-0111-3

Boell, S. K., \& Cecez-Kecmanovic, D. (2015). On Being 'Systematic' in Literature Reviews in IS. Journal of Information Technology, 30(2), 161-173. https://doi.org/10.1057/9781137509888_3

Bojö, J. (1991). The Economics of Land Degradation: Theory and Applications to Lesotho. Stockholm School of Economics, Economics Research Institute.

Bookchin, M. (1987). Social Ecology Versus Deep Ecology: A Challenge for the Ecology Movement. Green Perspectives: Newsletter of the Green Program Project, 4-5.

Boulding, K. E. (1966). The economics of the coming spaceship earth. In H. Jarrett (Ed.), Environmental Quality Issues in a Growing Economy. pp. 3-14

Brereton, P., Kitchenham, B. A., Budgen, D., Turner, M., \& Khalil, M. (2007). Lessons From Applying the Systematic Literature Review Process Within the Software Engineering Domain. Journal of Systems and Software, 80(4), 571-583. https://doi.org/10.1016/j.jss.2006.07.009

Breure, A. M., Lijzen, J. P. A., \& Maring, L. (2018). Soil and Land Management in a Circular Economy. The Science of the Total Environment, 624, 1125-1130. https://doi.org/10.1016/j.scitotenv.2017.12.137

Buiter, W. H. (2003). James Tobin: An Appreciation of His Contribution to Economics. The Economic Journal, 113(491), F585-F631. https://doi.org/10.1046/j.0013-0133.2003.00170.x

Burlakovs, J., Kriipsalu, M., Klavins, M., Bhatnagar, A., Vincevica-Gaile, Z., Stenis, J., Jani, Y., Mykhaylenko, V., Denafas, G., Turkadze, T., Hoglanda, M., Rudovica, V., Kaczala, F., Rosendal, R. M., \& Hogland, M. (2017). Paradigms on Landfill Mining: From Dump Site Scavenging to Ecosystem Services Revitalization. Resources, Conservation and Recycling, 123, 73-84. https://doi.org/10.1016/j.resconrec.2016.07.007

Cann, O. (2015). Seven Ways Geo-economics is Changing the Global Economy. Retrieved March 11, 2018 from https://www.weforum.org/press/2015/02/seven-ways-geo-economics-ischanging-the-global-economy/

Costanza, R., Wainger, L., Folke, C., \& Mäler, K.-G. (1993). Modeling Complex Ecological Economic Systems: Toward an Evolutionary, Dynamic Understanding of People and Nature. In Ecosystem Management (pp. 148-163). Springer, New York, NY. 
Dasgupta, P. S., \& Heal, G. M. (1979). Economic theory and exhaustible resources. Cambridge University Press.

de Groot, R., Fisher, B., Christie, M., Aronson, J., Braat, L., Gowdy, J., Haines-Young, R., Maltby, E., Neuville, A., Polasky, S., Portela, R., \& Ring, I. (2010). Integrating the Ecological and Economic Dimensions in Biodiversity and Ecosystem Service Valuation. In P. Kumar (Ed.) The Economics of Ecosystems and Biodiversity: The Ecological and Economic Foundations. London and Washington: TEEB.

European Academies' Science Advisory Council. (2015). Circular Economy: A Commentary From the Perspectives of the Natural and Social Sciences. Belgium: European Academies Science Advisory Council.

European Commission. (n. d.). Horizon 2020: Bioeconomy. Retrieved March 15, 2018 from http://ec.europa.eu/programmes/horizon2020/en/h2020-section/bioeconomy

European Environment Agency. (2011). Chapter 4: Natural Resources and Waste. Retrieved March 10, 2018 from https://www.eea.europa.eu/soer/synthesis/synthesis/chapter4.xhtml

Forde, E. (2017). The Ethics of Energy Provisioning: Living Off-Grid in Rural Wales. Energy Research \& Social Science, 30, 82-93. https://doi.org/10.1016/j.erss.2017.06.018

Gill, S. E., Handley, J. F., Ennos, A. R., \& Pauleit, S. (2007). Adapting Cities for Climate Change: The Role of the Green Infrastructure. Built environment, 33(1), 115-133. https://doi.org/10.2148/benv.33.1.115

Government of the Netherlands. (n. d.). Circular Economics: From a Linear to Circular Economy. Retrieved March 14, 2018 from https://www.government.nl/topics/circular-economy/from-alinear-to-a-circular-economy

Grahl, J., \& Lysandrou, P. (2003). Sand in the Wheels or Spanner in the Works? The Tobin Tax and Global Finance. Cambridge Journal of Economics, 27(4), 597-621. https://doi.org/10.1093/cje/27.4.597

Grant, M. J., \& Booth, A. (2009). A Typology of Reviews: An Analysis of 14 Review Types and Associated Methodologies. Health Information \& Libraries Journal, 26(2), 91-108. https://doi.org/10.1111/j.1471-1842.2009.00848.x

Hallegatte, S., Henriet, F., \& Corfee-Morlot, J. (2011). The Economics of Climate Change Impacts and Policy Benefits at City Scale: A Conceptual Framework. Climatic Change, 104(1), 51-87.

Hetemäki, L., Hanewinkel, M., Muys, B., Ollikainen, M., Palahí, M., Trasobares, A. (2017). Leading the Way to a European Circular Bioeconomy Strategy. European Forest Institute.

Jiang, L., \& O'Neill, B. C. (2017). Global urbanization projections for the Shared Socioeconomic Pathways. Global Environmental Change, 42, 193-199. https://doi.org/10.1016/j.gloenvcha.2015.03.008

Kotval-K, Z., Meitl, C., \& Kotval, Z. (2017). Should the Public Sector Play a Greater Role Funding Brownfield Redevelopment Projects? A Transatlantic Comparison. International Planning Studies, 22(4), 366-383. https://doi.org/10.1080/13563475.2017.1296760

Kvinikadze, G. (2016). Towards a Reconceptualization of Geo-Economics: Evolution of Concept Definition. $\quad$ Retrieved from https://www.researchgate.net/profile/Giorgi_Kvinikadze/publication/318650324_The_problem _of_geo-economics_definition/links/59845531458515946723cced/The-problem-of-geoeconomics-definition.pdf

Li, P., Omani, N., Chaubey, I., \& Wei, X. (2017). Evaluation of Drought Implications on Ecosystem Services: Freshwater Provisioning and Food Provisioning in the Upper Mississippi River Basin. International Journal of Environmental Research and Public Health, 14(5), 496. https://doi.org/10.3390/ijerph14050496

Mäler, K. (1974). Environmental Economics. John Hopkins University Press.

Martin, J., \& Henrichs, T. (2012). Environmental Indicator Report 2012 - Ecosystem Resilience and Resource Efficiency in a Green Economy in Europe. Retrieved March 9, 2018 from https://www.eea.europa.eu/publications/environmental-indicator-report-2012/environmentalindicator-report-2012-ecosystem/authors.xhtml

Matthew, R. A., Brown, O., \& Jensen, D. (2009). From Conflict to Peacebuilding: The Role of Natural Resources and the Environment. UNEP/Earthprint. 
McKinstry, C., Brown, T., \& Gustafsson, L. (2014). Scoping Reviews in Occupational Therapy: The What, Why, and How to. Australian Occupational Therapy Journal, 61(2), 58-66. https://doi.org/10.1111/1440-1630.12080

Meadows, D. H., Meadows, D. L., Randers, J., \& Behrens, W. W. (1972). The Limits to Growth. New York: Potomac Associates - Universe Books, 102, 27.

Meijide, A., Gruening, C., Goded, I., Seufert, G., \& Cescatti, A. (2017). Water management reduces greenhouse gas emissions in a Mediterranean rice paddy field. Agriculture, ecosystems \& environment, 238, 168-178.

Mirza, M. M. Q. (2003). Climate Change and Extreme Weather Events: Can Developing Countries Adapt?. Climate Policy, 3(3), 233-248. https://doi.org/10.3763/cpol.2003.0330

Naeem, S., Cao, C., Waqar, M. M., Wei, C., \& Acharya, B. K. (2018). Vegetation Role in Controlling the Ecoenvironmental Conditions for Sustainable Urban Environments: A Comparison of Beijing and Islamabad. Journal of Applied Remote Sensing, 12(1), 016013. https://doi.org/10.1117/1.jrs.12.016013

Nkonya, E., Gerber, N., von Braun, J., \& De Pinto, A. (2011). Economics of Land Degradation. IFPRI Issue Brief, 68.

Nkonya, E., Mirzabaev, A., \& von Braun, J. (Eds.). (2016). Economics of Land Degradation and Improvement: A Global Assessment for Sustainable Development. Springer Open.

Nobelprize.org. (n. d.). The Sveriges Riksbank Prize in Economic Sciences in Memory of Alfred Nobel 1981: James Tobin. Retrieved March 13, 2018 from https://www.nobelprize.org/nobel_prizes/economic-sciences/laureates/1981/

Patomäki, H. (2001). Democratising Globalisation: The Leverage of the Tobin Tax. Zed Books.

Qadir, M., Quillérou, E., Nangia, V., Murtaza, G., Singh, M., Thomas, R. J., Drechsel, P. \& Noble, A. D. (2014). Economics of Salt-Induced Land Degradation and Restoration. Natural Resources Forum, 38(4), 282-295. https://doi.org/10.1111/1477-8947.12054

Ramirez-Almeyda, J., Elbersen, B., Monti, A., Staritsky, I., Panoutsou, C., Alexopoulou, E., Schrijver, R. \& Elbersen, W. (2017). Assessing the Potentials for Nonfood Crops. In Modeling and Optimization of Biomass Supply Chains (pp. 219-251). https://doi.org/10.1016/b978-012-812303-4.00009-4

Robinson, A. K. (2017). The Growth of Singapore and Hong Kong in the Face of Climate Change and Environmental Degradation. International Immersion Program Papers, 64.

Schmidt, O., Padel, S., \& Levidow, L. (2012). The Bio-Economy Concept and Knowledge Base in a Public Goods and Farmer Perspective. Bio-Based and Applied Economics, 1(1), 47-63.

Shao, M., Tang, X., Zhang, Y., \& Li, W. (2006). City Clusters in China: Air and Surface Water Pollution. Frontiers in Ecology and the Environment, 4(7), 353-361. https://doi.org/10.1890/1540-9295(2006)004[0353:ccicaa]2.0.co;2

Smith, V. L. (1972). Dynamics of waste accumulation: disposal versus recycling. The Quarterly Journal of Economics, 86(4), 600-616.

Stecher, H., \& Bailey, M. (1999). Time for a Tobin Tax? Some practical and political arguments.

Tupenaite, L., Lill, I., Geipele, I., \& Naimaviciene, J. (2017). Ranking of Sustainability Indicators for Assessment of the New Housing Development Projects: Case of the Baltic States. Resources, 6(4). https://doi.org/10.20944/preprints201708.0082.v1

von Braun, J., Gerber, N., Mirzabaev, A., \& Nkonya, E. (2013). The Economics of Land Degradation. ZEF Working Paper No. 109. https://doi.org/10.2139/ssrn.2237977

Vörösmarty, C. J., Green, P., Salisbury, J., \& Lammers, R. B. (2000). Global water resources: vulnerability from climate change and population growth. Science, 289(5477), 284-288.

Wende, W., \& Darbi, M. (2018). Urban ecosystem services and biodiversity offsets. In B. Müller, H. Shimizu (Eds.), Towards the Implementation of the New Urban Agenda (pp. 39-47). Springer, Cham. https://doi.org/10.1007/978-3-319-61376-5_3

Yourdictionary.com. (n. d.). Geoeconomics. Retrieved March 9, 2018 from http://www.yourdictionary.com/geoeconomics\#RM30sY4sVDDFMD6I.99 


\section{AUTHORS' SHORT BIOGRAPHIES}

Jānis Zvirgzdiṇš, Mg. oec., obtained the degree of Bachelor of Electrical Science in 2015. In 2018, he obtained the Professional Master's degree in Urban and Regional Engineering Economics and earned the qualification of an Economist. From 2016 to 2018, J. Zvirgzdins worked as a Duty Officer of Radiation Safety Centre of State Environmental Service. His main research areas are green economics, circular economics, intellectual urban environment, renewable and nuclear energy and radiation safety. He received the Award in Final Paper Competition of the Latvian Association of Power Engineers and Energy Constructors in 2015.

Kaspars Plotka, Mg. oec., obtained the degree of Bachelor of Science in Business Administration and Management in 2005 (Business Institute "RIMPAK Livonija"). In 2017, he obtained the Professional Master's degree in Urban and Regional Engineering Economics. He is a Lecturer, a $\mathrm{PhD}$ student and Research Assistant within the Institute of Civil Engineering and Real Estate Economics, Faculty of Engineering Economics and Management, Department of Territorial Development Management and Urban Economics, Riga Technical University. He is the author and co-author of more than 20 scientific publications. His main research areas are the intellectual urban environment, the concept of a city, urban management, risk management, TQM, ecological economics, the evaluation of synergy, etc.

ORCID iD: http://orcid.org/0000-0001-9440-8215

Sanda Geipele, Dr. oec, Assoc. Prof., Riga Technical University, Latvia. Work experience has been acquired both in the private sector and in public administration, including real estate tax administration for several years at Riga City Council's Municipal Revenue Department. Research interests: sustainability development problems of real estate market, household resource management, construction industry, including land use management and institutional economics. She is the author and co-author of more than 60 scientific publications, including scientific monograph "Management System of Real Estate Market Development in Latvia" (2015) and two monographs with co-authors. She is an expert in management and economic sciences of the Latvian Council of Science.

ORCID iD: http://orcid.org/0000-0002-4721-5944 